\title{
Economic Analysis and Production Techniques of Snail Farms in Southern Greece
}

\author{
Hatziioannou M. , Issari A., Neofitou C., Aifadi S., Matsiori S. \\ University of Thessaly, School of Agricultural Sciences, Department of Ichthyology and Aquatic Environment, Fytoko Street, N. Ionia \\ Magnesia’s, Greece \\ *Corresponding author: mxatzi@uth.gr
}

Received October 16, 2014; Revised November 11, 2014; Accepted November 24, 2014

\begin{abstract}
In the present study was examined the economic viability and the production techniques of commercial snail farms, grounded in Peloponnese (Southern Greece). The primary data were collected through personal interviews from a sample of nine snail farms, during the years of 2009 and 2010. The farms produce fresh snails Cornu aspersum, raised and reproduced in net covered greenhouses with vegetation and artificial food provision. The impact of the production cost and the selling price on the business profitability was examined. A comparative presentation of profits and expenses was conducted for the economic viability control and the Net Present Value criterion was applied, as an indication of potential profitability of the investment plan. The net cash flows were estimated for a time period of ten years and sensitivity analysis was applied for a variation rate of $20 \%$ (with $5 \%$ as the discounting interest rate). The initial investment was $19.478 €, 60 \%$ of this concerns expenses for the creation of the net covered greenhouse. The annual revenue was estimated to $20.028 €$ during an average year ( $3^{\text {rd }}$ year) within the ten-year evaluation horizon. In the selling price of $5,3 € / \mathrm{kg}$ the investment was deemed marginally economically viable. Problems which concerned mainly the design of the livestock installations but also the productions techniques were detected. Sensitivity analysis, demonstrated that the enterprise was sensitive to variations of the product's selling price (of fresh snails) and less sensitive to variations of feeding cost (of the green vegetables and artificial diet). Heliciculture has the potential to constitute an innovative and viable agricultural activity with economic, social and environmental benefits.
\end{abstract}

Keywords: Heliciculture, snail production, Cornu aspersum, investment drawing, sensitivity Analysis, Greece

Cite This Article: Hatziioannou M., Issari A., Neofitou C., Aifadi S., and Matsiori S., "Economic Analysis and Production Techniques of Snail Farms in Southern Greece.” World Journal of Agricultural Research, vol. 2, no. 6 (2014): 276-279. doi: 10.12691/wjar-2-6-5.

\section{Introduction}

Terrestrial snails and their products are favoured by an increasing number of consumers in European countries, Southeast Asia and America, where a great demand for edible snails is observed. In Europe, the annual consumption of snails exceeds 100,000 metric tons and European snails' imports from 1995 to 2010 had a 49\% increment ([1,2]). Heliciculture (Snail farming) is an excellent alternative to obtain edible snails and is a relatively new field of agricultural production in Greece $([3,4])$. Due to favourable climatic conditions and a great interest of mostly young people towards activation in this field, Heliciculture has developed in the last decade. According to [5], today in Greece there are 136 snails' farms which occupy an area of 575 acres. Of these, 75 are open-air type which occupy an area of 481.50 acres, and 56 intensive (net covered houses) type which occupy an area of 93.19 acres. From the total of 13 counties of Greece, Peloponnese demonstrates the highest number (17) of intensive farms and Central Macedonia follows with 16.
The rest of the counties demonstrate a scarce or a small number (1-7) of farms.

The edible land snail Cornu aspersum (Helix aspersa), which is widely known with its French name «Petis gris», and in Greece as "Kritikos kochlios” (Crete's snail), demonstrates a special interest for the Greek market, both in production and export level [6].

No economic study on snail farming in Greece has been published so far, while international researchers are concerned with tropical and developing countries $([7,8]$, [9]) where the use of mini-livestock can be less resourceconsuming, and if properly managed could represent an alternative to the current livestock production system [10]. Older data have been published for European countries $([11,12])$ and Australia also $([13,14])$.

The purpose of the present study is the economic viability evaluation of a hypothetical enterprise of a mini livestock farming system grounded in Southern Greece, in an area where the main use of land is for agriculture and stock breeding. The snail farm produces fresh snails Cornu aspersum, raised and reproduced in net covered greenhouses with vegetation and artificial food provision.

The impact of the production cost and the selling price on the business profitability was examined. A comparative 
presentation of profits and expenses was conducted for the economic viability control and the Net Present Value criterion was applied, as an indication of potential profitability of the investment plan [15].

The methods concerning the data collection, the technical description and the production characteristics of the snails' farms and the analytical tools for the economic evaluation are presented in Section 2. The results and their discussion are presented in the two following sections.

\section{Methods}

\subsection{Data Collection}

The primary data come from a sample of nine snail farms, from a total of ten that were operating in the research area (Arkadia, Peloponnese, Greece). The farms were constructed at the same period, immediately after the destructive fire which struck the area in the summer of 2007, and share similar constructive characteristics and the same product the edible snail Cornu aspersum. Their differences regard technical characteristics, initial livestock, feeding and snail treatment.

Data were collected through personal interviews (indepth interviews) with the entrepreneurs and those responsible for the production of the snail farms during the years of 2009 and 2010. The selection of nonstructured interviews, instead of a questionnaire is due to the heterogeneity of the sample, as far as the size and degree of the organization are concerned [16]. During the period of research, the 10nth snail unit was not operating commercially; hence, data could not been offered.

\subsection{Farms Technical Description}

Each farm net covered greenhouse is a multiple modified arch, with a total surface of $1000 \mathrm{~m}^{2}$. The roof is covered with a permeability net from $40 \%$ to $50 \%$, while the side openings are covered with a great permeability net (hole dimensions $>4 \mathrm{~cm}^{2}$ ). The livestock installation has not been established lengthwise of the perimeter, where an iron plate has been placed. All farms afford the required ancillary installations and irrigation system. In the net house interior there were long compartments for breeding and fattening of the snails, feeders (plastic or clay, of different sizes) and wooden shelters of different shapes and sizes. On the ground, apart from the halls covered with gravel, other plants are cultivated; the Medicago sativa, and the Trifolium repens as well as the aromatic Rosmarinus officinalis and Lavandula angustifolia.

\subsection{Analytical Tools}

In order for the economic viability control of the farms to be estimated, the Net Present Value criterion was applied, as an indication of potential profitability of the investment plan. The calculation of the Net Present Value (NPV) arises from the equation:

$$
N P V=-C_{i n}+\sum_{t=1}^{N} \frac{F_{t}}{(1+d)^{t}}
$$

Here: $C_{\text {in }}$ initial investment, $F_{t}$ annual net profit, $N$ economic life cycle of the investment and $d$ interest rate in present value (desirable capital rate).

The criterion of Internal Rate of Return (IRR) was applied, which constitutes the interest rate and results from the equation of the present value of cash flow and the present value of outflow and relates the return of the investment with its capital cost as in [17]. It is defined as the solution of the equation:

$$
N P V_{d=I R R}=0
$$

Here: NPV the present value, as determined by equation (1), while the indication $d=I R R$ implies that the equation is solved to $\mathrm{d}$. When IRR is bigger than the capital cost, the investment is accepted; when it is smaller it is rejected and when IRR equals the capital cost the investment is marginal and evaluated appropriately. The aforementioned economic indicators are particularly used for the evaluation of any investment related to the increase of biological reserves and aquaculture as in [18].

The net cash flows were estimated for every year and for a time period of ten years. The methodological approach was based on a bioeconomic pattern, the functional parameters of which were determined according to regional data, provided that the national legislation does not pose limitations. The bioeconomic model chosen consists of three inter-dependent submodels: i) biological, ii)management and iii)financial.

\subsection{Farms Operation Data}

According to the production design, the enterprise production will be zero during the first year of operation, and from the second year and then, the annual return will be $100 \%$. The enterprise will operate at a $70 \%$ rate of its productivity in the first year-period, while in the second at a 90\%. Hence, the expenses (food, ancillary materials, staff, and livestock premiums) are evaluated proportionally for the first year of operation.

For the estimation of the used food value a convertibility indicator was used (F.C.R), which equals 3 when the food is vegetables and 2 when the food is ration (based on the data delivered by the producers). The average price of food is $0,80 € / \mathrm{Kg}$ for vegetables and 0,58 $€ / \mathrm{Kg}$ for ration (market prices).

Here, it is important to note that the snail farm was designed to operate on the personal work of its owner in order to simulate the real enterprises operating in the research area. Thus, family works, as well as the owner's administrative skills were not taken into consideration for our estimations. Assessments, concerning the number of those employed, are based on the hypothesis that the enterprise is in need of a scientific person in charge, whose annual compensation for consulting is 667€, and an occasional unskilled worker, whose annual compensation was estimated at $900 €$.

Fixed data depreciations were estimated with the fixed method. They constitute part of the annual cost of production and amount to $3.088 €$ per year in the first five years of the enterprise operation and $327 €$ in the following five years. Sensitivity analysis was applied for a variation rate of $20 \%$. The discount rate was selected to be $5 \%$ following others studies with evaluate the validity of 
investments at primary sector with the same investments risk [18].

\section{Results}

The hypothetical enterprise was a "commercial snail farm” grounded in Southern Greece with a net covered greenhouse of $1000 \mathrm{~m}^{2}$ as the main livestock installation. The only product of the particular installation was living snails with an average production capacity of 3,777 Kg snails annually.

The enterprise accomplishes sales only in the internal marker, either wholesale (89\% of the production) or retail (the remaining 11\%). The wholesale selling price was $5 € / \mathrm{kg}$ of living snails, according to enterprises' data. Retail sales are analyzed as followed: $95 \%$ goes to restaurants in the price of $8 € / \mathrm{kg}$ and $5 \%$ to various customers in the price of $3 € / \mathrm{kg}$. The weighted price of sales was estimated to $5,3025 € / \mathrm{Kg}$ in living snails.

Based on the estimations concerning the production volume, selling price and expenses flow, the hypothetical enterprise will require an initial investment of $19.478 €$ (Table 1). From this sum, 60\% will concern expenses for the creation of the net covered greenhouse.

Table 1. Analysis of capital cost of snail farming enterprise (in €)

\begin{tabular}{|c|c|}
\hline Class of Expenditure & Cost $(€)$ \\
\hline Territorial extend & 1.617 \\
\hline Machinery & 200 \\
\hline Technical work & 1.144 \\
\hline Net covered greenhouses & 11.861 \\
\hline Technical installations & 800 \\
\hline Technical knowledge purchase & 857 \\
\hline Other equipment & 1.499 \\
\hline Patch formation & 1.500 \\
\hline Total & 19.478 \\
\hline
\end{tabular}

The annual revenue from the proposed enterprise operation results from the sales of the produced snails and is estimated to $20.028 €$ during an average year ( $3^{\text {rd }}$ year) within the ten-year evaluation horizon (Table 2). The snail farm requires $13.700 €$ of annual variable expenses during an average year ( $3^{\text {rd }}$ year), within the ten-year evaluation horizon, which makes up $75 \%$ of the total production cost. Spawn expenses are estimated to 255€ and feeding expenses rise up to $13.445 €$. The fixed cost was estimated at $4.680 €$ during the five first years of enterprise operation, in which depreciation of the livestock installation takes place. In the following five years fixed costs come to $1.919 €$.

Table 2. Operating account (in $€$ )

\begin{tabular}{|c|c|c|c|c|c|}
\hline Year & $1^{\text {st }}$ & $2^{\text {nd }}$ & $3^{\text {rd }}-5^{\text {th }}$ & $6^{\text {th }}-9^{\text {th }}$ & $10^{\text {th }}$ \\
\hline Total turnover & 14.019 & 18.025 & 20.028 & 20.028 & 20.028 \\
\hline Minus: selling cost & 11.182 & 13.922 & 15.292 & 15.292 & 15.292 \\
\hline Operational outcome $^{1}$ & 2.837 & 4.103 & 4.736 & 4.736 & 4.736 \\
\hline Plus: various income $^{1}$ & 0 & 0 & 0 & 0 & 2.408 \\
\hline Outcomes $^{2}$ & 2.837 & 4.103 & 4.736 & 4.736 & 7.144 \\
\hline Minus : depreciation $^{3}$ & 3.088 & 3.088 & 3.088 & 327 & 327 \\
\hline Outcome prior interest $^{\text {Ond }}$ & -251 & 1.015 & 1.648 & 4.409 & 6.817 \\
\hline
\end{tabular}

${ }^{1}$ from selling fixed assets,

${ }^{2}$ prior depreciation and interest

${ }^{3}$ non-funded investment part
Table 2 presents the operating account of the enterprise under evaluation for the first ten years of its operation. Based on that, the result, prior to depreciation and interests in an average operating year, amounts to $4.736 €$. The break-even point of the investment comes to $2.802 \mathrm{Kg}$ and the production capacity to $74,2 \%$, thus the evaluated investment is viable, with an average selling price of 5 , $3 € / \mathrm{Kg}$. In this sales price $(5,3 € / \mathrm{Kg})$, the financial evaluation of the enterprise for the ten-year period results in a positive NPV, equal with $16.187 €$ and in a positive IRR, equal with $18 \%$. The investment is considered marginally viable.

Sensitivity analysis, which was applied for a variation rate of $20 \%$, demonstrated that the enterprise was sensitive to variations of the product's selling price (of fresh snails) and less sensitive to variations of feeding cost (of the green vegetables and artificial diet). Thus, a reduction of $20 \%$ in the selling price would result in a negative NPV, while a $+20 \%$ rise in the price would almost double NPV (31.127, $95 €$ ). On the other hand, the fluctuations in the price do not significantly alter NPV, which ranges from $13.5541,1 €$ with a $-20 \%$ reduction to $18.515,34 €$ for a $+20 \%$ rise.

\section{Discussion}

The hypothetical enterprise, the viability of which was examined in the present study, was a commercial snail farm of a small range, with its main livestock installation a net covered greenhouse of $1000 \mathrm{~m}^{2}$. The only product of this particular exploitation was living snails of the Cornu aspersum, while the production was not vertically integrated. $60 \%$ of the initial investment concerns expenses for the creation of the net covered greenhouse. In similar studies, the total cost of the initial installation was $\$ 27.754$ and $\$ 22.590$ in Australia $([13,14])$.

The investment has been designed to be financed by private capital. This finding also agrees with the findings in [9] that $96 \%$ and $98 \%$ of the snail farmers used their personal savings as a source of initial capital. The annual variable expenses make up $75 \%$ of the total production cost while the fixed cost was estimated at $4.680 €$ during the five first operating years of the enterprise - in which the depreciation of the snail farm takes place - and $1.919 €$ for the fifth until the tenth year. According to [13], the variable and fixed costs of the enterprise he evaluated was \$7.585 and \$1.975 accordingly, while in a corresponding study in Nigeria the fixed cost was $18,1 \%$ of the total [9].

In the selling price of $5,3 € / \mathrm{kg}$ and under the hypotheses posed, the investment was deemed marginally economically viable. Problems which concerned mainly the design of the livestock installations but also the administration of the livestock capital were detected. The competition in commercial snail farming mainly focuses on the achievement of highest meat quality at the best possible price due to the vulnerability of the product. If the specific activity is regarded as an enterprise of an average risk, like aquacultures, then the minimum value of IRR that has to be estimated in order for the enterprise to be economically viable and capable of attracting investors, is $13-16 \%$, as it has been determined for the aquaculture field [18]. Sensitivity analysis showed that the enterprises were more sensitive to variations of selling price and less 
sensitive to those of feeding costs, a result particularly encouraging for intensive feeding systems with artificial diets [19]. Previous papers have posed the view that a diet only based on green vegetables does not offer a sufficient growth rate for the support of commercial snail farming, although these systems are very common in Mediterranean areas ([11,20]).

Heliciculture, as a development activity in Greece, forms an alternative source of income even in areas with farm land of low capacity; yet, it requires the know-how and experience, as mentioned for the field of aquaculture as well. The long-term potential of snail farming is positive; however, the development and the correct function of the market are required; in other words the vertical integration of the market. The potential, nonetheless, is positive owing to the reduction of natural populations in the main countries of production, the increase of international demand and the recognition of the high nutritional value of snails meet. Heliciculture has the potential to constitute an innovative and viable agricultural activity with economic, social and environmental benefits; the restraint of agricultural populations, the supply of the local market with secure products, the vertical integration of the agricultural field and finally the protection of the snails natural populations are some of them.

\section{References}

[1] Morei, V., "Heliciculture-perspective business in the context of sustainable development of rural areas" Scientific Papers Series Management, Economic Engineering in Agriculture and Rural Development, 12: 3, 2012.

[2] Oikonomou, S., Polymeros, K., and Galanopoulos, K., "Investigating the dynamics of Greek exports in the E.U snails market”, in Proceedings of the 12th conference of the Greek Association of Agricultural Economics (GAAE), 2012.

[3] Hatziioannou, M., Exadaktilos, A., Panagiotaki, P., Lazaridou, M. and Neofitou, C., Setting quality standards for farmed snails Helix aspersa. Final Report, Pythagoras II, Ministry of Education and Religious Affairs, Volos, 2008, p168.

[4] Berillis, P., Hatziioannou, M., Panagiotopoulos, N. and Neofitou, C., "Similar shell features between rear and wild Cornu aspersum snails”, World Journal of Agricultural Research, 1: 1-4. 2013.

[5] Anonymus, Heliciculture in Greece, Document d'information, Directorate General of Animal Production, Hellenic Ministry of
Rural Development and Food, Athens, 2012. Available: www.minagric.gr/.

[6] Morin, R., Élevage de l'escargot, Document d'information DADD-16, Ministère de l'Agriculture, des Pêcheries et de l'Alimentation, 1999. Available: www.mapaq.gouv.qc.ca/Fr/Pech/

[7] Chaitanawisuti, N., Kritsanapuntu, S., and Natsukari, Y., "Economic analysis of a pilot commercial production for spotted Babylon, Babylonia aerolata (Link 1807), of marketable sizes using a flow-through culture system in Thailand”, Aquaculture Research, 33: 1265-1272. 2002.

[8] Cobbinah, J., Vink, A., and Onwuka, B., Snail farming production, processing and marketing, Agromisa Foundation, Wageningen Netherlands, 2008. [E-book] Available: http://www.agromisa.org/

[9] Ogunniyi L.T., "Economic analysis of snail production in Ibadan, Oyo state”, International Journal of Agricultural Economics \& Rural Development, 2(1): 26-34, 2009.

[10] Paoletti, M. G., Ecological Implications of Minilivestock. Insects, Rodents, Frogs and Snails. Science Publishers Inc., Enfield, New Hampshire, USA, 2005.

[11] Bonnet, J.C., Aupinel, P. and Vrillon, J.L., L'escargot Helix aspersa: biologie-élevage, Institute National de la Recherche Agronomique, Paris, 1990, p124.

[12] Elmslie L. J., "Snail Farming in fields pens in Italy" British Crop Protection Council Monograph, 41:19-25. 1989.

[13] Murphy, B., Breeding and growing snails commercially in Australia, RIRDC-Rural Industries Research Development Corporation, Publication No. 00/188, Kingston, Australia, 2001. [E-book] Available: www.rirdc.gov.au/.

[14] Begg, S., Free-range snail farming in Australia, RIRDC-Rural Industries Research and Development Corporation, Publication No 06/104, Kingston, Australia, 2006. [E-book] Available: www.rirdc.gov.au/.

[15] Ryan, P.A. and Eyan, G.P., "Capital budgeting practices of the Fortune 1000: How have things changed?”, Journal of Business and Management, 8:152-168, 2002.

[16] Felzensztein, C., and Gimmon, E, “The influence of culture and size upon inter-firm marketing cooperation: A case study of the salmon farming industry”, Marketing Intelligence \& Planning, 25 (4). 377-393. 2007.

[17] Fama, E.F., and French, K.R., “The Corporate Cost of Capital and the Return on Corporate Investment”, The Journal of Finance, 54: 1939-1967. 1999.

[18] Garcia Garcia, J. and Garcia Garcia B., “An econometric viability model for ongrowing sole (Solea senegalensis) in tanks using pumped well sea water" Spanish Journal of Agricultural Research, 4: 304-315. 2006.

[19] García, A., Perea, J., Martín, R., Acero, R., Mayoral, A., Peña, F., and Luque, M., "Effect of two diets on the growth of the Helix aspersa Müller during the juvenile stage”, in Proceedings of the 56th Annual Meeting EAAP Uppsala, 1-9. 2005.

[20] Staikou, A. and Lazaridou-Dimitriadou, M., "Feeding experiments on and energy flux in a natural population of the edible snail Helix lucorum L. (Gastropoda: Pulmonata: Stylommatophora) in Greece”, Malacologia, 31: 217-227. 1989. 